\title{
FEDERAL AND STATE PRECEDENTS ON DOING BUSINESS: JURISDICTION OVER FOREIGN CORPORATIONS UNDER ERIE*
}

THE fusion of substance and procedure characterizing a host of judicial and legislative rules plagues application of Erie R.R. v. Tompkins. ${ }^{1}$ At once criticized and defended, ${ }^{2}$ the Erie doctrine requires federal courts to apply state substantive law to nonfederal questions in suits based on diversity jurisdiction. ${ }^{3}$ Matters procedural under state law are substantive for purposes of Erie when a federal court's disregard of the state procedure would significantly affect the result of a suit. ${ }^{4}$ Yet the use of some federal statutes to secure in federal courts results unobtainable in state tribunals has not been challenged as improperly extending federal regulation beyond the confines of procedure."

*K. Shapiro, Inc. v. New York Cent. R.R., 152 F. Supp. 722 (E.D. Mich. 1957).

1. 304 U.S. 64 (1938).

2. See, e.g., Clark, State Law in the Federal Courts: The Brooding Omnipresence of Erie v. Tompkins, 55 YaLE L.J. 269 (1946) ; Shulman, The Demise of Swift v. Tyson, 47 YALE L.J. 1336 (1938).

3. Cohen v. Beneficial Industrial Loan Corp., 337 U.S. 541, 555 (1949); Ragan v. Merchants Transfer \& Warehouse Co., 337 U.S. 530, 532-33 (1949).

4. Guaranty Trust Co. v. York, 326 U.S. 99, 109 (1945) (statute of limitations); Cities Serv. Oil Co. v. Dunlap, 308 U.S. 208, 212 (1939) (burden of proof); see Cohen v. Beneficial Industrial Loan Corp., supra note 3, at 555-56 (state law requiring shareholders in derivative suits to give security for reasonable expenses which corporation may incur).

An attempt has been made to avoid the historical terms "substantive" and "procedural" in connection with Erie because of the different context. Words and phrases such as "determinative," "different outcome" and "significantly affect" are often used instead. See, e.g., Guaranty Trust Co. v. York, supra at 109.

5. The Federal Interpleader Act, 28 U.S.C. $\$ 1335$ (1952), with its nationwide service of process, 28 U.S.C. $\$ 2361$ (1952), permits federal adjudications of issues involving multistate claimants that state courts cannot handle because of their more limited jurisdiction. This act has frequently been classified as remedial and never questioned under Erie. See Austin v. Texas-Ohio Gas Co., 218 F.2d 739 (5th Cir. 1955) (remedial classification) ; Tollett v. Phoenix Assurance Co., 147 F. Supp. 597 (W.D. Ark. 1956) (same); see also Griffin v. McCoach, 313 U.S. 498 (1.941) (forum's conflict of laws rule applied under Erie, but extraterritorial service not challenged); Blair Holdings Corp. v. Bay City Bank \& Trust Co., 234 F.2d 513 (9th Cir. 1956) (interpleader based on diversity but out-of-state service unchallenged).

The Declaratory Judgment Act also permits divergent results in those states not having such statutes. 28 U.S.C. $\$ \S 2201-02$ (1952), as amended, 28 U.S.C. $\$ 2201$ (Supp. IV, 1957). The Supreme Court has held the act procedural only. Aetna Life Ins. Co. v. Haworth, 300 U.S. 227, 240 (1937) ; Skelly Oil Co. v. Phillips Petroleum Co., 339 U.S. 667, 671 (1950). In Skelly, the Court stated: "[T] hat the declaratory remedy which may be given by federal courts may not be available in the State courts is immaterial." Id. at 674. This case, while not mentioning Erie expressly, would seem to quiet any notions about conflict with Erie. Such arguments had been raised, however, prior to Skelly. Developments in the Law-Declaratory Judgments, 62 HARv. L. REv. 787, 804-05 (1949) ; Clark, supra note 2, at 279; Tunks, Categorisation and Federalism: "Substance" 
Thus, in specific cases, federal courts have been left with the responsibility of drawing a difficult line between procedure and substance-a problem compounded by the knowledge that Erie may be based on constitutional grounds and that their holdings, even if unwise, may not be correctable by Congress. ${ }^{8}$

In the recent case of $K$. Shapiro, Inc. $v$. New York Cent. R.R., a federal district court considered whether the requirement of "doing business" within a state for purposes of service of process was procedural or substantive under Erie. ${ }^{7}$ The plaintiff Shapiro, a Michigan corporation, sued the New York, New Haven \& Hartford Railroad, a foreign corporation, in a federal district court in Michigan and based jurisdiction on diversity. ${ }^{8}$ The defendant moved

and "Procedure" After Erie Railroad v. Tompkins, 34 ILL. L. Rev. 271, 295 \& n.123 (1939); see note 25 infra and accompanying text.

The ban on labor injunctions in the Norris-LaGuardia Act, 47 Stat. 70 (1932), 29 U.S.C. $\S \S 101,104,107$ (1952), may also raise questions in states without similar proscriptions. Clark, supra note 2, at 279; Tunks, supra at 295 n.123; Note, 41 CoLUM. L. REv. 104, 108-15 (1941). A state court, if not barred by state law, can issue a labor injunction. See, e.g., Southern Bus Lines v. Amalgamated Ass'n of Street Employees, 205 Miss. 354, 378, 38 So. 2d 765, 770 (1949); United Elec. Workers v. Westinghouse Elec. Corp., 65 F. Supp. 420, 422 (E.D. Pa. 1946). Nor can the defendant remove to a federal court to enjoy Norris-LaGuardia protection. See Home Bldg. Corp. v. Carpenters Council, 53 F. Supp. 804, 807 (W.D. Mo. 1943) (dictum). See also Yoerg Brewing Co. v. Brennan, 59 F. Supp. $625,629-30$ (D. Minn. 1945) (federal court has no jurisdiction to grant labor injunction); MOORE, Judicial CODE 220-21 (1949) (removal jurisdiction keyed to original jurisdiction).

At present, federal courts have no original quasi-in-rem jurisdiction. See Davis v. Ensign-Bickford Co., 139 F.2d 624 (8th Cir. 1944). They can, however, retain jurisdiction over a removed case which was inaugurated in a state court under its quasi-in-rem jurisdiction. See Clark v. Wells, 203 U.S. 164 (1906). If uniformity of result in all courts, state and federal, within a state is accepted as the desired goal, federal courts should be given quasi-in-rem jurisdiction. Such jurisdiction has been recommended by the Advisory Committee on the Rules of Civil Procedure, but has not been enacted. See Moore, Federal Rules and Official Forms 70-71 (1956).

6. See 304 U.S. at 77-78; Bernhardt v. Polygraphic Co., 350 U.S. 198, 202, 208 (1956); Kurland, Mr. Justice Frankfurter, the Supreme Court and the Erie Doctrine in Diversity Cases, 67 Y ALE L.J. 187, 188-205 (1957).

Statutory grounds also exist for the use of local law in diversity cases. See, e.g., Rules of Decision Act, 28 U.S.C. $\$ 1652$ (1952) ; Cohen v. Beneficial Industrial Loan Corp., 337 U.S. 541, 555 (1949); Woods v. Interstate Realty Co., 337 U.S. 535, 538 (1949) (dissenting opinion).

7. 152 F. Supp. 722,725 (E.D. Mich. 1957).

8. Id. at 723 .

The defendant New Haven was referred to as a "foreign corporation" without specifying its citizenship. The New Haven is incorporated in more than one state, and therefore may be treated as having more than one citizenship in diversity cases. See Marshall v. Baltimore \& O.R.R., 57 U.S. (16 How.) 314 (1853) (while corporation is not a citizen of its state of incorporation, all of its shareholders are conclusively presumed to be citizens of that state); Moore, Judicial Code 156 (1949) ; McGovney, A Supreme Court Fiction, Corporations in the Dizerse Citizenship Jurisdiction of the Federal Courts, 56 HARv. L. REv. 853 (1943) ; cf. Doctor v. Harrington, 196 U.S. 579, 587 (1905) (presumption that 
to quash service and dismiss on the ground that it was not doing business in Michigan. ${ }^{9}$ The court denied the motion and, while noting that the Michigan and federal precedents were identical, held the defendant amenable to process in accordance with prior federal decisions on doing business. ${ }^{10}$

The court thus effectively classified doing business as procedural even though it admitted that Supreme Court decisions holding enforceability of claims and capacity to sue substantive would suggest the application of state

all shareholders are citizens of state of incorporation not applicable when shareholder is suing his corporation).

Confusion has arisen where the plaintiff is a citizen of one of the defendant's states of incorporation. The circuits are split on the proper treatment in such circumstances. The First Circuit holds that the corporation must be regarded in each state of incorporation as solely domesticated therein. Thus, a noncitizen of the forum state can sue the corporation in a state of incorporation even if both plaintiff and defendant are citizens of another state, but a citizen plaintiff could not. Seavey v. Boston \& Me. R.R., 197 F.2d 485 (1st Cir. 1952). The Third Circuit, however, holds that a plaintiff citizen can treat the defendant corporation as' a citizen of any other state in which it is incorporated. Gavin v. Hudson \& M.R.R., 185 F.2d 104 (3d Cir. 1950). Both circuits agree that a foreign corporation compelled to incorporate in a state in order to do business there is not a citizen of that state for purposes of diversity. See Southern R.R. v. Allison, 190 U.S. 326 (1903). A recent First Circuit case denying jurisdiction was affirmed by the Supreme Court without discussion, citing Seavey v. Boston \& Me. R.R., supra. Jacobson v. New York, N.H. \& H.R.R., 206 F.2d 153 (1st Cir. 1953), aff'd, 347 U.S. 909 (1954). For a case denying jurisdiction where a plaintiff, a citizen of $X$, sued a defendant, incorporated in $X$ and $Y$, in the district court of $Z$, see Waller v. New York, N.H. \& H.R.R., 127 F. Supp. 863 (S.D.N.Y. 1955). The problem is discussed in 34 B.U.L. Rev. 495 (1954) ; 6 V and. L. Rev. 398 (1953).

9. 152 F. Supp. at 723 .

10. Id. at 725 .

Often, however, the state standard is more restrictive, and resolution of the Erie question is crucial. See, e.g., Riverbank Laboratories v. Hardwood Products Corp., 220 F.2d 465, 467 (7th Cir. 1955), rev'd, 350 U.S. 1003 (1956) ; General Elec. Co. v. Masters Mail Order Co., 122 F. Supp. 797, 800 (S.D.N.Y. 1954). Compare Kenny v. Alaska Airlines, Inc., 132 F. Supp. 838, 853-54 (S.D. Cal. 1955) (nonresident airline not doing business in accordance with state precedents although another airline within the state sold defendant's tickets), with Scholnik v. National Airlines, Inc., 219 F.2d 115 (6th Cir.), cert. denied, 349 U.S. 956 (1955) (nonresident airline was doing business in accordance with federal precedents because another airline within the state sold defendant's tickets); Note, 56 CoLunr. L. Rev. 394, 400 n.39 (1956).

On the other hand, some states go further than the Supreme Court did in International Shoe Co. v. Washington, 326 U.S. 310 (1945) (solicitation of orders by resident agents sufficient doing business for jurisdiction). MD. ANN. CoDE art. 23, $\$ 92$ (d) (1957) (contract or an act done within the state sufficient for jurisdiction); VT. STAT. \& 1562 (1947) (same). Both of these statutes have been held constitutional. Compania De Astral, S.A. v. Boston Metals Co., 205 Md. 237, 107 A.2d 357 (1954); Smyth v. Twin State Improvement Corp., 116 Vt. 569, 80 A.2d 664 (1951). For a discussion of these cases, see 50 Nw. U.L. Rev. 425 (1955) ; Comment, 22 U. ChI. L. Rev. 674 (1955). A North Carolina statute extends jurisdiction even further by making corporations subject to suit in any cause of action arising out of production, manufacture or distribution of goods of such corporation with the reasonable expectation that those goods are to be used or consumed in the state and are so used or consumed. N.C. Sess. Laws 1955, c. 1143, $\$ 1$. This statute, however, has been held invalid as applied to the facts of two cases. 
precedents. $^{11}$ In concluding that federal law was applicable, it relied on a later per curiam opinion by the Supreme Court. ${ }^{12}$ The Seventh Circuit, which had employed local doing business precedents, was there reversed, and the district court decision reinstated. The use of this case as controlling precedent, however, appears erroneous. The Supreme Court opinion was so terse that its basis is not discernible. ${ }^{13}$ The earlier adverse holdings were not even cited, much less distinguished. More important, the district court ruled orally, and

See Putnam v. Triangle Publications, Inc., 245 N.C. 432, 96 S.E.2d 445 (1957) ; Erlanger Mills, Inc. v. Cohoes Fibre Mills, Inc., 239 F.2d 502 (4th Cir. 1956).

The definition of doing business is currently undergoing major changes. In McGee v. International Life Ins. Co., 355 U.S. 220 (1957), a Texas state court refused to enforce a California judgment on the ground that it was void under the Fourteenth Amendment. The California judgment was based on service of process on the defendant by registered mail in Texas. The defendant's only contact with California was that it had assumed a life insurance policy on a California resident, and the insured had paid premiums to the defendant from California. The Texas Court of Civil Appeals affirmed, McGee v. International Life Ins. Co., 288 S.W.2d 579 (Tex. Civ. App. 1956), but the Supreme Court reversed, holding that the Texas court must give full faith and credit to the California judgment because it was based on substantial contact with the state.

A more recent case has gone beyond even the $\mathrm{McGee}$ decision. The Louisiana "direct action" statute permitting an injured party to sue the tortfeasor's insurer directly has been given new scope by an amendment to Louisiana's nonresident motorist statute. The amendment provides for suit against the nonresident's insurer directly through substituted service on the Secretary of State. A federal court in Louisiana upheld jurisdiction over an Oklahoma insurance company served in accordance with this statute. The company's sole contact with Louisiana was its policy covering the nonresident tortfeasor. See Pugh v. Oklahoma Farm Bureau Mut. Ins. Co., 26 U.S.I. WeEK 1121 (E.D. La. Jan. 11, 1958).

11. 152 F. Supp. at 725 .

In Angel v. Bullington, 330 U.S. 183 (1947), the Supreme Court held that, since the state courts would not entertain a deficiency suit, a federal court sitting in that state would be similarly limited. In Woods v. Interstate Realty Co., 337 U.S. 535 (1949), the Supreme Court held that where a state had closed its courts to corporate plaintiffs not complying with state requirements, a federal court in that state would also have to refuse jurisdiction. See note 19 supra.

Lower federal courts have been divided on the precise issue of the principal case, but have numerically favored a state definition. Notes, 56 CoLUN. L. REv. 394, 398 n.27 (1956) (advocating federal definition), 5 DukE B.J. 129, 130 (1.955) (same); see cases collected in Kenny v. Alaska Airlines, Inc., supra note 10, at 845-46 \& nn.6-9.

12. 152 F. Supp. at 725. See Riverbank Laboratories v. Hardwood Products Corp., 350 U.S. 1003 (1956), reversing per curiam 220 F.2d 465 (7th Cir. 1955), on remand, 236 F.2d 255 (7th Cir. 1956).

13. The opinion in full is as follows: "The Court is of the opinion that the District Court correctly found there was proper service upon the defendant in this case. Accordingly, the judgment of the Court of Appeals is reversed and the case is remanded to that Court for further proceedings." 350 U.S. at 1003.

On remand, the Seventh Circuit remarked: "Our difficulty is, there was no opinion by the Surreme Court with which to conform. We interpret the order to mean that for some reason still unknown to us, the service upon the defendant was good ...." $236 \mathrm{~F} .2 \mathrm{~d}$ at 256.

Cornmentators have also noted the opacity of the Supreme Court opinion. Kurland, supia note 6 , at 211-12 n.120. 
the record did not specify whether its decision was guided by federal precedents or a view of state law contrary to that of the Seventh Circuit. The Supreme Court opinion, therefore, may have been based on approval of the district court's interpretation of local precedents rather than acceptance of doing business as procedural. ${ }^{14}$

14. In the court of appeals, the plaintiff argued that additional factors distinguished the venerable Illinois precedents and brought the defendant within the court's jurisdiction. 220 F.2d at 467 . The plaintiff never contended that Illinois precedents were irrelevant.

Remarks in the Riverbank Transcript of Record indicate that the parties and the district court itself were inarticulate, making no clear distinction between federal and state precedents. Some passages, though, may intimate that the district court was applying local law. The court said: "I will hear you fully, Mr. Fox [counsel for the defendant], but you show me an Illinois Supreme Court case that the Federal Court here must follow the state law, however we may dislike it or however different it may be in other states. Show me an Illinois case, if you have one, with facts that are like the facts in the case at bar. We will suppose that the corporation was not doing business within the state." Transcript of Record, pp. 169-70, Riverbank Laboratories v. Hardwood Products Corp., Civil No. 54 C 300, N.D. Ill., June 3, 1954. The request for a state decision requiring a federal court to follow its pronouncement is puzzling, but the court appears to have thought that the Illinois cases cited by the defendant were distinguishable on their facts, the position taken by the plaintiff on appeal. And the court implied that a cogent Illinois case denying jurisdiction, if found, would have been followed. Earlier, the court had stated: "I know you contend, Mr. Fox, that mere solicitation of orders, accepted and filled in another state, does not constitute doing business under the decisions of Illinois. There is no quarrel with the Illinois holdings. Mere solicitation of orders does not constitute doing business ...." Id. p. 167. The district court could not have been referring to federal precedents because under federal law solicitation is probably enough. See Scholnik v. National Airlines, Inc., 219 F.2d 115, 118-19 (6th Cir.), cert. denied, 349 U.S. 956 (1955); International Shoe Co. v. Washington, 326 U.S. 310 (1945); Moore, Judrcial Code 57 (1949). See also Woodworkers Tool Works v. Byrne, 191 F.2d 667, 672 (9th Cir. 1951) (applying International Shoe as federal precedent); Latimer v. S/A Industrias Reunidas F. Matarazzo, 175 F.2d 184 (2d Cir.), cert. denied, 338 U.S. 867 (1949) (same).

The court completed its sentence, stating: "[T]he mere maintenance of an office also does not constitute doing business, but, I ask you, does the maintenance of an office, the employment of an agent to solicit business, resulting in a large volume of business, coupled, as it is here, with an agent who capably assisted contractors and architects in solving the problems peculiar to their structures, and investigating and recommending solutions of complaints, in addition to the other tests, doesn't that turn the balance so that it is more fair to hold that the foreign corporation is doing business in Illinois than to hold to the contrary." Transcript of Record, p. 167, Riverbank Laboratories v. Hardwood Products Corp., supra. While the circuit court expressly applied state law and found the defendant's activity to be mere solicitation, 220 F.2d at 467 , the district court constantly stressed, as did the plaintiff, the additional facts that distinguished this case from the precedents relied on by the appellate court and defendant, Transcript of Record, pp. 167, 169, 170, 171, Riverbank Laboratories v. Hardwood Products Corp., supra.

Although the district court went on to cite several federal cases on doing business, $i d$. pp. 167-68, it returned to its principal theme after the defendant cited two Seventh Circuit cases requiring the use of local precedent: "Now, may I inquire whether in that case [the Seventh Circuit case] there was anything done besides taking orders, as is the fact here." Id. p. 169.

See also Kurland, supra note 6, at 211-12 n.120 (supporting the position that the Riverbank district court may have been relying on a modern view of Illinois law). 
Arguments have been made by some courts and commentators that doing business is procedural. ${ }^{15}$ And jurisdiction has traditionally been so classified. ${ }^{16}$ While such tradition is always relevant, especially if federal rather than state, it is not conclusive under Erie. ${ }^{17}$ Doing business has been analogized to venue which is procedural both historically and under Erie.18 On the

15. 2 Moore, Federal Practice 970 (2d ed. 1948) ; Notes, 56 Colum. L. Rev. 394, 399 (1956), 1957 Wrs. L. REv. 337, 5 DukE B.J. 129, 135 (1955) ; see, generally, cases collected in Kenny v. Alaska Airlines, Inc., 132 F. Supp. 838, 845 n.7 (S.D. Cal. 1955).

16. See, e.g., Mechanical Appliance Co. v. Castleman, 215 U.S. 437, 443 (1910); David Lupton's Sons Co. v. Automobile Club, 225 U.S. 489 (1912) ; Angel v. Bullington, 330 U.S. 183, 198 (1947) (dissenting opinion of Mr. Justice Reed: "In matters of procedure and jurisdiction, I take it, no one would contend that the doctrine of Eric Railroad is applicable."); Stephenson v. Grand Trunk W.R.R., 110 F.2d 401, 405 (7th Cir.), cert. granted, 310 U.S. 623, dismissed by stiptlation, 311 U.S. 720 (1940); 44 ILL. L. REv. 533, $535 \&$ n.15 (1949). It has been suggested in order to avoid the impact of Erie that jurisdiction be separately classified. Note, 41 CoLun. L. REv. 104, 120-21 (1941). Nothing more would seem to be gained by this approach than by accepting for Erie the historical classification of procedural.

Commentators have struggled to retain this procedural classification, despite the inroads of Eric, in order to allow leeway where needed in the administration of the federal courts. Notes, 56 Colum. L. Rev. 394, 398-402 (1956), 69 Harv. L. Rev. 508, 523-24 (1956), 30 IND. L.J. 324 (1955) ; see note 36 infra.

17. See Guaranty Trust Co. v. York, 326 U.S. 99, 109-10, 116 (1945) ; Cohen v. Beneficial Industrial Loan Corp., 337 U.S. 541, 555 (1949); Palmer v. Hoffman, 318 U.S. 109 (1943) ; Cities Serv. Oil Co. v. Dunlap, 308 U.S. 208 (1939) ; Notes, 49 Colum. L. REv. 852, 853 (1949), 24 IND. L.J. 418, 423 n.20 (1949).

18. State law has not been used to control venue in federal courts. See, e.g., Mississippi Publishing Corp. v. Murphree, 326 U.S. 438, 442 (1946); Steel Motor Serv. Inc. v. Zalke, 212 F.2d 856, 858 (6th Cir. 1954); McCoy v. Siler, 205 F.2d 498, 499 (3d Cir. 1953) ; Note, 56 Colum. L. Rev. 394, 402 n.46 (1956) ; cf. Jerome v. United States, 318 U.S. 101 (1943) (state law cannot be used to interpret federal statute).

The use of "doing business" in the federal venue statute, 28 U.S.C. $\S 1391$ (c) (1952), however, has caused confusion in determinations of personal jurisdiction over corporations, see Notes, 30 Ind. L.J. 324, 334-35 (1955), 5 Duke B.J. 129, 134 (1956), 69 HARv. L. Rev. 508, 51S-19 (1956). Courts do not always distinguish between jurisdiction over corporations and venue. See, e.g., Anschell v. Sackheim, 145 F. Supp. 447, 453-54 (D.N.J. 1956); Cooke v. Kilgore Mfg. Co., 105 F. Supp. 733 (N.D. Ohio 1952); Goldstein v. Chicago, R.I. \& P.R.R., 93 F. Supp. 671 (W.D.N.Y. 1950). And those that do often assume that doing business for personal jurisdiction is the same as doing business for venue. See Ronson Art Metal Works, Inc. v. Brown \& Bigelow, Inc., 104 F. Supp. 716, 724 (S.D.N.Y. 1952) ; Moore v. Atlantic C.L.R.R., 98 F. Supp. 375, 382 (E.D. Pa. 1951). Riverbank Laboratories v. Hardwood Products Corp., 350 U.S. 1003 (1956), has been cited in this regard. Denis v. Perfect Parts, Inc., 142 F. Supp. 259, 261 n.1 (D. Mass. 1956). One commentator urges the use of federal doing business precedents for jurisdiction in order to avoid possible confusion arising from one uniform federal venue definition of doing business and forty-eight varying state jurisdictional definitions of doing business. Barrett, Ventue and Service of Process in the Federal Courts-Suggestions for Reform, 7 Vand. L. Rev. 608, 619 (1954).

Venue and personal jurisdiction should not be equated. The federal venue statute resulted from Neirbo Co. v. Bethlehem Shipbuilding Corp., 308 U.S. 165 (1939). Moore, Judictal Code 56-57 (1949); Note, 69 Harv. L. REv. 508, 517 (1956). This case tied federal venue directly to state licensing requirements, $i . e$., sufficient business to require a 
other hand, equal if not closer analogies can be drawn to enforceability of claims, capacity to sue and statutes of limitations which are substantive for Erie despite procedural traditions. ${ }^{19}$ Possibly the closest similarities are to forum non conveniens and immunity of parties and witnesses from service of process. The lower federal courts, however, are split on the classification of these rules, and the Supreme Court, through express refusal in the former instance and lack of occasion in the latter, has not resolved the controversy. ${ }^{20}$ In any event, none of these analogies is compelling.

license. See Remington Rand, Inc. v. Knapp-Monarch Co., 139 F. Supp. 613,617 (E.D. $\mathrm{Pa}$. 1956). Courts have generally held that more activity is required to subject corporations to state licensing requirements than to make them amenable to service of process. See Bendix Home Appliances, Inc. v. Radio Accessories Co., 129 F.2d 177, 181 (8th Cir. 1942) ; Liquid Veneer Corp. v. Smuckler, 90 F.2d 196, 202 (9th Cir. 1937); McMaster v. Robinson's Womens Apparel, Inc., 45 F. Supp. 99 (D. Neb. 1942) ; Vicksburg, S. \& P. Ry. v. De Bow, 148 Ga. 738, 98 S.E. 381 (1919). Since the doing business required for the federal venue statute is based on licensing requirements, it would therefore appear greater than that required for service of process. See Remington Rand, Inc. v. KnappMonarch Co., supra at 617-18. Similarly, if continuous activity is not involved, jurisdiction may exist by the commission of a single act within the state, yet such an act by itself does not satisfy venue requirements. See Olberding v. Illinois Cent. R.R., 346 U.S. 338 (1953) ; Notes, 30 IND. L.J. 324, 335-36 (1955), 69 HARv. L. Rev. 50S, 519 (1956). Specific federal regulatory statutes, however, occasionally require less activity for venue than to sustain service of process. See, e.g., Clayton Act, 38 Stat. 736 (1914), 15 U.S.C. $\S 22$ (1952) ; Eastman Kodak Co. v. Southern Photo Materials Co., 273 U.S. 359, 37072 (1927) ; Noerr Motor Freight, Inc. v. Eastern R.R. Presidents Conference, 113 F. Supp. 737, 746-47 (E.D. Pa. 1953) ; Naifeh v. Ronson Art Metal Works, Inc., 111 F. Supp. 491, 493 (W.D. Okla. 1953).

If the quantum of activity were the same for venue and jurisdiction, whenever venue over a foreign corporation was deemed improper, there would be a fatal service defect. Thus, while federal law authorizes transfer if venue is improper, 28 U.S.C. $\$ 1406$ (a) (1952), barring waiver, transfer of actions against foreign corporations would not be possible because of defective service, see Remington Rand, Inc. v. Knapp-Monarch Co., supra at 618.

Even if the same requirements satisfied both, they need not be treated in the same way under Erie, since the substantive elements of the two may differ.

19. See Angel v. Bullington, 330 U.S. 183 (1947) (enforceability of a claim) ; Woods v. Interstate Realty Co., 337 U.S. 535 (1949) (capacity to sue). A substantive classification under Erie of personal jurisdiction over corporate defendants is consistent with, and a logical extension of, these decisions. In practice, a refusal to take a case for reasons of jurisdiction is similar to a refusal grounded on a defense created by local law such as the statute of limitations. See Guaranty Trust Co. v. York, 326 U.S. 99 (1945). See also note 11 supra.

20. While forum non conveniens does not involve jurisdiction in a strict sense, the decision of a court not to exercise its jurisdiction may be just as conclusive as the court's decision that it does not have jurisdiction. Thus, if in a given situation state $A$ would dismiss, the plaintiff would be required to sue in state $B$, the convenient forum. If the federal court in state $A$ would not dismiss, and if state $B$ would apply its own law, the existence of a federal court would enable the plaintiff to choose between two substantive laws. See notes 22,25 infra.

The possible violation of Erie has been squarely before the Supreme Court on three occasions, but the Court has refused to rule. Williams v. Green Bay \& W.R.R., 326 U.S. 
The policy of Erie suggests that the doing business requirement be gov-

549, 558-59 (1946) ; Gulf Oil Corp. v. Gilbert, 330 U.S. 501, 509 (1947) ; Koster v. Lumbermens Mut. Cas. Co., 330 U.S. 518, 529 (1947). The lower federal courts are discordant. Compare Weiss v. Routh, 149 F.2d 193, 195 (2d Cir. 1945) ; Grismer v. Merger Mines Corp., 43 F. Supp. 990 (E.D. Wash. 1942), with Overfield v. Pennroad Corp., 113 F.2d 6 (3d Cir. 1940); Koster v. Lumbermens Mut. Cas. Co., 153 F.2d 888 (2d Cir. 1946), aff'd on other grounds, 330 U.S. 518 (1947). These cases are discussed in Note, 46 Colun. L. Rev. 413, 425-29 (1946) ; Braucher, The Inconvenient Fortum, 60 HARv. L. REv. 908, 927-30 (1947).

The passage of the Federal Transfer of Venue Act has introduced an additional factor. 28 U.S.C. $\$ 1404$ (a) (1952). The Supreme Court has held that the district court has broader discretion in the application of $\$ 1404$ (a) than under the doctrine of forum non conveniens. Norwood v. Kirkpatrick, 349 U.S. 29, 30 (1955). Accordingly, a federal court applying $\$ 1404$ (a) would transfer cases where the state court could not dismiss under forum non conveniens. The use of $\$ 1404(\mathrm{a})$ could result in the application of different substantive law whether the transferee federal court applied the law of the transferor state or of the transferee state. Thus, if the suit is transferred from a federal court in state $A$ to a federal court in state $B$, and the federal court in $B$ applies the law of the state in which it sits, it would apply the law of state $B$. The same case in a state court in $A$, however, might not be dismissed and the law of state $A$ would apply. But if a state court in state $A$ would dismiss under forum non conveniens, the federal court in state $A$ would almost certainly transfer. In a state court action, the plaintiff would have to start again in state $B$ where the law of $B$ would apply. Yet if the federal court in state $B$ after the transfer considered the suit a state $A$ suit, it would be bound to apply the law of $A$. If the plaintiff started in a state court, the defendant could remove to the federal court, thereby raising the same difficulties. The problem has received attention from several commentators. Currie, Change of Venue and the Conflict of Lazws, $22 \mathrm{U}$. CHI. L. REv. 405 (1955) ; Kaufman, Observations on Transfers Under Section 1404(a) of the Neve Judicial Code, 10 F.R.D. 595 (1951) ; Kaufman, Futher Oberservations on Transfers Under Section 1404(a), 56 COLUM. L. REv. 1 (1956). A solution appears possible under Erie. If the state would dismiss, the transferee federal forum should apply the law of the state in which it sits, that being the forum in which the plaintiff would have to bring suit after dismissal in the state court. If the state would not dismiss, the transferee federal forum should apply the law of the transferor forum. The administrative difficulties of such a rule are manifest and are probably sufficient to deter any court from employing it. Currie, supra at 447.

But even aside from the administrative impracticalities, further difficulties confront the transferee federal court in applying this rule. The theory behind requiring the federal court in the transferee state to apply the law of the transferee state is that the plaintiff would have to bring suit there after dismissal in the transferor state. But if the plaintiff has a choice of states in which to sue the defendant, and is not limited to the transferee state, the proposed solution is no help to the transferee federal court which must then go ahead and resolve the problem on another basis.

Questions related to those raised by forum non conveniens arise from the concept of internal affairs of foreign corporations. Many state courts have long refused to hear suits involving the internal affairs of a corporation of another state, even if brought by a resident shareholder. The federal courts had adopted this doctrine, whether or not it applied in the state where the federal court sat. Rogers v. Guaranty Trust Co., 288 U.S. 123 (1933). Fourteen years later, however, the Supreme Court held in effect that the "internal affairs" rule should be treated as part of forum non conveniens. Koster v. Lumbermens Mut. Cas. Co., 330 U.S. 518 (1947). This decision seems to create an Erie problem in that a federal court probably would not consider a suit by a resident shareholder against a foreign corporation doing business in the state as inconvenient, while a state court might 
erned by state law. ${ }^{21}$ Failure by federal courts to use local precedents could alter the applicable law. If, in Shapiro, defendant had not been doing business under Michigan law, use of federal precedents would have yielded jurisdiction and subsequent judgment, both unobtainable in Michigan courts. Were Michigan substantive law applied under these circumstances, the ultimate result might not have been obtainable in any state court. Thus, generally, to the extent that federal courts rely on federal law to determine such questions as doing business and, jurisdiction so gained despite contrary state interpretations, proceed to judge the merits according to the law of the state in which they sit, a proliferation of available law is inevitable. ${ }^{22}$ Plaintiffs are

dismiss on these facts alone under the internal affairs rule. See cases collected in Note, 46 Colum. L. Rev. 413, 415 n.12 (1946). Some states, in accord with the federal courts' current position, treat the problem under forum non conveniens. See, e.g., Royal China, Inc. v. Regal China Corp., 304 N.Y. 309, 107 N.E.2d 461 (1952). For a discussion of the problem, see Comment, 56 YaLE L.J. 1234 (1947) ; Notes, 46 Colum. L. REv. 413 (1946), 58 CoLum. L. Rev. 234 (1958).

Immunity from service of process of parties, witnesses and counsel affords a particularly close parallel to doing business. Both involve state policy toward exercising jurisdiction over certain defendants, and the consequences of denial of jurisdiction are the same. The few authorities available are divergent. Compare Hardie v. Bryson, $44 \mathrm{~F}$. Supp. 67 (E.D. Mo. 1942), with Goade v. Vollrath, 81 F. Supp. 971, 973 (W.D. Mo. 1948). The Hardie case is discussed in 56 Harv. L. Rev. 135 (1942); 91 U. PA. L. Rev. 160 (1942) ; 2 Moore, Federad Practice 951 n.3 (2d ed. 1948).

21. The generally conceded historical justification for diversity jurisdiction was to insure out-of-state litigants a trial free from local bias. Bank v. Deveaux, 9 U.S. (5 Cranch) 37, 50 (1809) ; Martin v. Hunter's Lessee, 14 U.S. (1 Wheat.) 141, 160 (1816); Guaranty Trust Co. v. York, 326 U.S. 99, 111-12 (1945) ; Yntema \& Jaffin, Preliminary Analysis of Concurrent Jurrisdiction, 79 U. PA. L. REv. 869, 880 (1931). But see Friendly, The Historic Basis of Diversity Jurisdiction, 41 Harv. L. REv. 483 (1928). The decisions in Erie and cases following it accordingly held that federal courts must apply state substantive law in order to achieve the same result as an impartial state court. Diversity cases are based on local causes of action. State interests are paramount; federal interests are secondary. Cf. Lumbermens Mut. Cas. Co. v. Elbert, 348 U.S. 48, 53-54 (1954) (concurring opinion). If a state does not feel it necessary, it need not extend its jurisdiction to the maximum. Perkins v. Benguet Consol. Mining Co., 342 U.S. 437 (1952); Woods v. Interstate Realty Co., 337 U.S. 535 (1949); Angel v. Bullington, 330 U.S. 183 (1947); 44 ILL. L. Rev. 533 (1949).

22. For example, if the defendant were doing business under federal precedents but not state, and if the cause of action were barred by statutes of limitations in all states other than Michigan, determination of doing business according to federal law could create the sole possibility of relief. For the statute of limitations is considered substantive under Erie, see note 4 supra, and the Michigan period of limitation would thus be applicable. Moreover, even if Michigan conflicts doctrine required reference to the laws of another jurisdiction, the action would still be maintainable under the Michigan statute. In conflict of laws, unlike Erie, statutes of limitations are considered procedural unless they create as well as limit the right in suit. See Restatement, Conflict of Laws $\$ \$ 603-05$ (1934) ; Goodrich, Conflict of Laws $\$ \$ 85-86$ (3d ed. 1949). Hence, the limitational period of the forum may be applied irrespective of the choice of substantive law. See RESTATEMENT, op. cit. supra \$\$ 584-85; GoodRrch, op. cit. supra $\$ \$ 0$.

More generally, in any situation in which the contacts in the state corresponding to Michigan, though not adequate for involuntary personal jurisdiction, are sufficient to 
allowed to choose an additional substantive law solely because of diversity of citizenship. Yet prevention of just such forum shopping was a principal objective of Erie. ${ }^{23}$ Admittedly, some rules and remedies lending themselves to similar forum shopping have been deemed procedural under Erie. ${ }^{24}$ Declaratory judgment and interpleader suits, for example, have been entertained in diversity cases even though they may afford a plaintiff a choice of forums with differing substantive laws unavailable but for his citizenship. ${ }^{\mathbf{5}}$

support application of the law of the forum under conflicts doctrine but, as seems likely, insufficient or not of a nature to induce a different state court, were the action commenced there, to refer to Michigan law, determination of doing business by application of federal law will create an additional substantive law available to the plaintiff.

23. 304 U.S. at 7477; see Guaranty Trust Co. v. York, 326 U.S. 99, 109 (1945); Lumbermens Mut. Cas. Co. v. Elbert, 348 U.S. 48, 56-57 (1954) (concurring opinion); Woods v. Interstate Realty Co., 337 U.S. 535, 538 (1949).

24. See note 5 supra.

Similarly, the power to transfer under $\S 1404$ (a) has not been challenged in litigation, but commentators have discussed the possibility of conflict with Erie. Kaufman, Observations on Transfers Under Section 1404(a) of the New Judicial Code, 10 F.R.D. 595, 599 (1951); Currie, supra note 20, at 410-14, 438-46; Note, 60 Y ALE L.J. 537, 538-39 (1951); see note 20 supra.

25. To illustrate, assume state $A$ has a declaratory judgment act and state $B$ does not, and that defendant $Y$, a corporation, is amenable to suit in both $A$ and $B$. So long as plaintiff $X$ does not share citizenship with $Y$, he may sue for a declaratory judgment in a federal court sitting in, and applying the law of, state $B$. Absent the Federal Declaratory Judgment Act and the federal court, however, he could have obtained relief only in the $A$ state court.

Griffin v. McCoach, 313 U.S. 498 (1941), exemplifies how the Federal Interpleader Act may also alter the applicable substantive law. There, a New Jersey insurance company filed an interpleader action in a district court in Texas against a Texas administrator and a New York trustee to determine which party was entitled to the proceeds of an insurance policy contracted in New York. The district court and the circuit court held the policy to be governed by the law of New York which dictated judgment for the trustee. The Supreme Court reversed, holding that Texas conflict of laws rules must be used in diversity cases, and remanded for determination whether Texas would apply its own laws or those of New York. If New York law applied, the trustee would have won according to the district and circuit courts' decisions. If Texas law applied and provided as the Texas administrator contended, the trustee's judgment would have been vacated. Without the Interpleader Act, the trustee could have sued in New York and collected. But because of that act and its nationwide service, the trustee's cause of action could be decided not under the law of New York but under the law of Texas. See HART \& Wechsler, The Federal Courts and the Federal System 636 (1953).

For a similar result under $\$ 1404$ (a) transfer orders, see note 20 sitpra.

In discussing Griffin v. McCoach, stopra, one commentator has taken the position that, since a federal court in a statutory interpleader suit has wider service of process than the courts of the state in which it sits, the federal court need not be considered in effect another court of that state. Thus, in such suits, the federal court would be freed from the requirements of cases like Guaranty Trust Co. v. York, 326 U.S. 99 (1945) (statute of limitations substantive under Erie), and Angel v. Bullington, 330 U.S. 183 (1947) (enforceability of claims substantive under Erie), which were based on the "another state court" rationale. Erie, however, was to remain as originally formulated and continue to bind the federal courts to state substantive law such as torts and contracts. Only the later 
But the cases are not irreconcilable. A distinction may be drawn between interpleader, declaratory judgment and like remedies, and capacity to sue or enforceability of claims. While all are traditionally procedural and all contain substantive elements, Congress has intervened to regulate in the former but not in the latter. ${ }^{26}$ More specifically, even according the status of acts of Congress to the Federal Rules of Civil Procedure, ${ }^{27}$ no attempted interpreta-

extensions of Erie as evidenced by cases like Guaranty and Angel were to be shelved in situations where state and federal process did not coincide. Accordingly, the argument runs, the federal court should not be bound by the state conflict of laws doctrine but allowed to develop and apply federal conflicts rules, notwithstanding the characterization of conflict of laws as substantive where state and federal process is coterminous. See Developments in the Lazo-Multiparty Litigation in the Federal Courts, 71 HARv. L. REv. 874, 924-26, 998 (1958).

Were this argument accepted, a congressional provision making process in district courts run within a 100-mile radius from the courthouse, as recommended by the Advisory Committee on the Rules of Civil Procedure, Moore, Frderal Rules and Official Forass 71 (1956), would result in a geographically biased Erie rule. Confined to torts and contracts where the circle drawn about the relevant federal court encompassed more than one state, Erie would enjoy full expression in district courts located in the larger states.

26. For the procedural background, see notes 5,16 supra; for the substantive elements, see notes 5, 24, 25 supra.

The suggested distinction would require a clear expression of congressional intent to regulate, as in the interpleader and declaratory judgment acts. See note 5 supra. Thus, in arbitration, which has a procedural background, see Shanferoke Coal \& Supply Corp. v. Westchester Serv. Corp., 293 U.S. 449 (1935) (prior to Erie arbitration act applied in diversity suit); Murray Oil Products Co. v. Mitsui \& Co., 146 F.2d 381, 383 (2d Cir. 1944) (after Erie arbitration act held procedural) ; Berkovitz v. Arbib, 230 N.Y. 261, 130 N.E. 288 (1921) (New York arbitration law held a form of procedure), and possible substantive elements, see Bernhardt v. Polygraphic Co., 350 U.S. 198 (1956), 45 CaLIF. L. REv. 87, the lack of a clear congressional intent to regulate, see Federal Arbitration Act, 9 U.S.C. $\$ \S 1-3$ (1952), resulted in narrow construction rather than procedural classification, see Bernhardt v. Polygraphic Co., supra at 201; Fairman, The Supreme Court, 1955 Term, 70 HARV. L. REV. 83, 138-41.

27. The rules are usually not considered acts of Congress. Sibbach v. Wilson \& Co., 312 U.S. 1, 18 (1941) (dissenting opinion of Mr. Justice Frankfurter): "Plainly the Rules are not acts of Congress and cannot be treated as such." In their promulgation, Congress did not elect to act itself but delegated the authority to the Supreme Court. 28 U.S.C. \& 2071 (1952). And once formulated and reported to Congress, the rules become effective by mere lapse of time. 28 U.S.C. $\S 2072$ (1952); FED. R. CIV. P. 86; MOORE, FEDERAL RULEs AND OfFictal Forars 14 (1956). However, the provision in the Enabling Act that the rules shall prevail over any other federal statute has been thought to give them the effect of acts of Congress. See Note, 62 HARv. L. REv. 1030, 1031 (1949). Others have assumed that the rules are acts of Congress.. See Note, 1957 WIs. L. REV. 337.

The relevance of Erie to the rules has received wide attention. See, e.g., Gavit, States' Rights and Federal Procedure, 25 IND. L.J. 1 (1949); Merrigan, Erie to York to RaganA Triple Play on the Federal Rules, 3 VaNd. L. Rev. 711 (1950); Notes, 38 Geo. L.J. 115 (1949), 62 HaRv. L. Rev. 1030 (1949), 66 Harv. L. Rev. 1516 (1953).

Most commentators feel that the promulgation of the rules and the decision in Eric were based on separate reasoning. Merrigan, supra at 715; MOORE, Judicial CoDE 317-18 (1949). And while the Enabling Act limited the effect of the rules to matters of procedure, Congress, unless prophetic, could not have intended so to label the rules for 
tion of doing business or regulation of personal jurisdiction over corporations can be found. ${ }^{28}$ Although rules $4(\mathrm{~d})(3)$ and $4(\mathrm{~d})(7)$ describe how process on a corporation is to be served, they do not designate when a corporation is subject to service. ${ }^{29}$ And rule eighty-two explicitly renounces for the rules any intent to extend or limit jurisdiction of the federal courts. ${ }^{30}$

The foundations of Erie indicate that a distinction based on congressional regulation is sound. Whether or not Erie is founded in the Constitution, the relations between central and local government it ordains are fundamental. ${ }^{31}$ Courts should, accordingly, be hesitant to enhance the reach of federal control by drawing fine distinctions between substance and procedure. So viewed, rules containing elements of both and readily classifiable as neither should be applied in accordance with state law. Congressional intervention, on the other hand, should, as in the interpleader and declaratory judgment areas, be accorded great weight. ${ }^{32}$ If Erie is not a constitutional pronouncement, its

purposes of Erie. The Supreme Court itself has not felt that it was foreclosed by either the Enabling Act or its own promulgation of the rules from considering their classification under Erie. Mississippi Publishing Corp. v. Murphree, 326 U.S. 438, 444 (1946). As a result, several rules have been questioned under Erie though the Supreme Court has sometimes avoided a direct answer. See, e.g., Cohen v. Beneficial Industrial Loan Corp., 337 U.S. 541, 556 (1949) (rule 23(b)) ; Ragan v. Merchants Transfer \& Warehouse Co., 337 U.S. $530,532-33$ (1949) (rule 3 ).

In Sibbach v. Wilson \& Co., supra, rules 35 and 37 were disputed as exceeding the powers granted the Supreme Court in the Enabling Act. The majority felt they were procedural rules, but Mr. Justice Frankfurter in his dissent felt there were substantive elements in rule 35 and stated that without explicit legislation by Congress such a change should not pass under the label of procedure. Id. at 18. The effect of Erie on these rules, however, was not discussed.

28. See, generally, Pulson v. American Rolling Mill Co., 170 F.2d 193, 194 (1st Cir. 1948); Charles Keeshin, Inc. v. Gordon Johnson Co., 109 F. Supp. 939, 942 (W.D. Ark. 1952) ; Note, $69 \mathrm{HARV}$. L. Rev. 508, 517 (1956). For a discussion of the possible applicability of the federal venue statute to personal jurisdiction, see note 18 supra.

29. 2 Moore, Federal Practice 969 (2d ed. 1948) ; Barron \& Holtzoff, 1 Federal Practice and Procedure $\$ \S 172,176,179$ (1950) ; Hart \& WeChSLER, op. cit. supra note 25 , at 959 .

Where rule 4(d) (7) has been used to effect service, courts have sometimes employed it as a basis for using state precedents on the ground that its wording, "in the manner prescribed by the law of the state," incorporated the state's definition of doing business. Such a construction seems strained, particularly since it would suggest application of state law in federal-question cases as well as in diversity cases. See cases collected in Kenny v. Alaska Airlines, Inc., 132 F. Supp. 838, 844 n.4 (S.D. Cal. 1955) ; Notes, 69 HARv. L. REv. 50S, 521 (1956), 30 IND. L.J. 324, 329-30 (1955).

30. 7 Moore, Federal Practice 4601 (2d ed. 1955). Rule 82 has been ignored by one commentator in assuming that the rules do govern jurisdiction. Note, 1957 WIs. L. REv. 337.

31. Mr. Justice Brandeis's opinion in Erie itself expresses the fundamental change wrought by Erie in federal and state relations. 304 U.S. at 71-80. And the Supreme Court has frequently iterated this basic policy. See, e.g., Guaranty Trust Co. v. York, 326 U.S. 99, 109 (1945).

32. The fundamental federal-state relations involved, see note 31 supra, dictate that a clear expression of congressional intent be required, $c f$. United States v. Fisher, 6 U.S. 
policies can, of course, be subordinated to an act of Congress. ${ }^{33}$ If Erie is constitutionally required, congressional discretion must be more limited..$^{34}$ Nevertheless, the broad considerations of federal-state relations which might be used to justify elevating Erie do not require perpetually rigid classification of intermixed substance and procedure. ${ }^{35}$ Mechanical leeway in the form of congressional review may be essential to efficient administration of the law. ${ }^{30}$

(2 Cranch) 214, 232 (1804) (where the general system of laws is departed from, the legislative intention must be expressed with irresistible clearness); Robertson v. Railroad Labor Bd., 268 U.S. 619, 627 (1925) (a congressional intent to depart from a longestablished policy is not lightly to be assumed). See also note 26 supra.

33. See notes $5,20,25$ supra.

The Rules of Decision Act provides that state law shall apply "except where . . . Acts of Congress otherwise require or provide." 28 U.S.C. $\$ 1652$ (1952); see Developments in the Lazw-Declaratory Judgments, 62 HARv. L. REv. 787, 804-05 (1949); Erie R.R. v. Tompkins, 304 U.S. 64, 78-80 (1938) ; Addressograph-Multigraph Corp. v. American Expansion Bolt \& Mfg. Co., 124 F.2d 706, 708 (7th Cir. 1941); Note, 1957 WIs. L. Rev. 337.

34. See Bernhardt v. Polygraphic Co., 350 U.S. 198, 202 (1956); cf. Erie R.R. v. Tompkins, supra note 33, at 78-79; Marbury v. Madison, 5 U.S. (1 Cranch) 137 (1803).

35. The policy behind Erie is not as interested in particulars as it is in focusing attention on the federal government's responsibilities and its relationship with the constituent states. Cohen v. Beneficial Industrial Loan Corp., 337 U.S. 541,559 (1949) (dissent) ; Guaranty Trust Co. v. York, 326 U.S. 99, 109-10 (1945) ; see Ragan v. Merchants Transfer \& Warehouse Co., 337 U.S. 530, 532 (1949); notes 31, 32 supra, 38 infra.

36. Mr. Justice Black in his dissent in United States v. Causby, 328 U.S. 256 (1946), decried the rigidifying effect constitutional decisions have on Congress and the courts: "Since the effect of the Court's decision is to limit, by the imposition of relatively absolute constitutional barriers, possible future adjustments through legislation and regulation which might become necessary with the growth of air transportation, and since in my view the Constitution does not contain such barriers, I dissent." Id. at 268 . "What adjustments have to be made, only the future can reveal." Id. at 274. "When these two simple remedial devices are elevated to a Constitutional level . . . they can stand as obstacles to better adapted techniques that might be offered by experienced experts and accepted by Congress." Id. at 275.

Mr. Justice Jackson expressed similar opinions in National Mut. Life Ins. Co. v. Tidewater Transfer Co., 337 U.S. 582, 585-86 (1949).

An illustration of how constitutionalizing technical rules may bar beneficial administrative reform or innovation is provided by $\$ 1404$ (a). See note 20 supra. If forum non conveniens and $\$ 1404$ (a) are considered substantive for Erie, and Erie is applied in all its constitutional rigor to these technical rules, then Congress would be without power to enact a transfer statute no matter how desirable from a standpoint of justice and efficiency. And as individual states are inherently without power to authorize transfer, such a provision would be forever blocked. If Erie is used only to set the policy limits, then Congress could enact a transfer statute if its intent to do so was clear. See text at note 26 supra. The Federal Interpleader Act furnishes a similar example. See note 5 supra. This act resulted from inherent jurisdictional limitations of the states. Harris v. Travelers Ins. Co., 40 F. Supp. 154, 156 (E.D. Pa. 1941) ; Metropolitan Life Ins. Co. v. Segaritis, 20 F. Supp. 739, 740 (E.D. Pa. 1937). If the act is categorized as substantive, stakeholders will often be without a forum competent to afford them protection from double payment. The act may have substantive elements, but to hold that the national government is without power to enact it, no matter how explicitly Congress expresses itself, is to stunt procedural 
Moreover, since reasonable men may, and do, differ on what affects the substantial rights of parties, congressional determinations that no significant substantive elements are involved in traditionally procedural matters should enjoy a strong presumption of correctness. ${ }^{37}$ Realizing that minor legislative errors in this context are unlikely to subvert basic constitutional tenets, courts themselves have recognized the wisdom of such a presumption in cases testing congressional grants of jurisdiction. ${ }^{38}$

Coupled with broader discretion in federal district courts to find state law, this distinction between legislative and judicial isolation of procedure from substance should make Erie a flexible and workable doctrine. ${ }^{39}$ Requiring

innovations in areas where justice and efficiency would seem to require them. Protecting the policy of Erie does not require forcing the danger of double liability on stakeholders or preventing transfer of cases without dismissal whenever convenience or administrative ease indicates.

37. Uniformity of opinion on what is substantive and procedural is rare. Mr. Justice Reed, dissenting in Angel v. Bullington, 330 U.S. 183, 198 (1947), said: "One may regret that the line of the Great Divide between substance and procedure cannot be clearly marked so that all may agree as to its location in any one case." In all recent cases before the Supreme Court on that issue, the Justices have been divided. See Guaranty Trust Co. v. York, 326 U.S. 99 (1945) (5-2 decision) ; Angel v. Bullington, supra (6-3 decision); Cohen v. Beneficial Industrial Loan Corp., 337 U.S. 541 (1949) (6-3 decision). And between two constructions of a congressional statute, one constitutional and one not, the courts will adopt that which will save the act. See, e.g., NLRB v. Jones \& Laughlin Steel Corp., 301 U.S. 1, 30 (1937) ; cf. United States v. Butler, 297 U.S. 1, 67 (1936).

38. In upholding the statute giving federal district courts jurisdiction of civil actions between citizens of the District of Columbia and citizens of the states, 28 U.S.C. $\S 1332$ (1952), the Court said: "The considerations which bid us strictly to apply the Constitution to congressional enactments which invade fundamental freedoms or which reach for powers that would substantially disturb the balance between the Union and its component states, are not present here. In mere mechanics of government and administration we should, so far as the language of the great Charter fairly will permit, give Congress freedom to adopt its machinery to the needs of changing times." National Mut. Ins. Co. v. Tidewater Transfer Co., 337 U.S. 582, 585-86 (1949). A district court in Virginia construing the same act observed: "Bearing in mind that it is the duty of the court to resolve reasonable doubts in favor of the validity of the Act . . . it is not at all apparent that Congress exceeded its powers under the Constitution ...." Winkler v. Daniels, $43 \mathrm{~F}$. Supp. 265, 268 (E.D. Va. 1942). The consensus of the lower federal courts, however, was to the contrary. See National Mut. Ins. Co. v. Tidewater Transfer Co., supra at 583-84 n.4 (collecting citations).

The Federal Declaratory Judgment Act has been held constitutional. Aetna Life Ins. Co. v. Haworth, 300 U.S. 227, 240 (1937). The Supreme Court, holding the act procedural only, said that Congress was acting within its delegated powers over federal courts and that the act need be deemed to fall within this ambit. Later, in Skelly Oil Co. v. Phillips Petroleum Co., 339 U.S. 667, 674 (1950), the Court expressly approved the use of the act in a diversity suit. The constitutionality of the Federal Interpleader Act has also been upheld. Cf. Fidelity \& Deposit Co. v. A. S. Reid \& Co., 16 F.2d 502, 504 (E.D. Pa. 1926). And in Griffin v. McCoach, 313 U.S. 498 (1941), no question was raised regarding Erie's applicability or the act's constitutionality. See note 5 supra.

39. At present, federal courts are required to follow all decisions of all state courts, except those that are not binding on other courts of the state. King v. United Commercial Travelers, 333 U.S. 153 (1948); Fidelity Union Trust Co. v. Field, 311 U.S. 169 (1940). 
lower federal courts to interpret in accordance with state prescriptions any rules which may, but probably would not, affect the applicable law without allowing them leeway in construing aged state precedents could result in evils as great as those Erie attempted to correct. ${ }^{40}$ Judicial treatment of doing business exemplifies these dangers. Strict adherence to Erie would very likely force federal courts to follow restrictive local definitions of doing business which would just as likely be rejected by many modern state tribunals. ${ }^{41}$

Thus, federal courts cannot project the present position of the state supreme court even if discernible from other sources. This restriction has been condemned by many. See, e.g., Clark, supra note 2 , at 290-95. See also note $40 \mathrm{infra}$. And it has recently been seriously weakened in Bernhardt v. Polygraphic Co., 350 U.S. 198, 205, 209-12 (1956), where both the majority and the concurring Justices made statements indicating an evaluation of old state precedent might be in order. These statements are only dicta, and lower federal courts will probably still feel bound by King and Field. For a concise history of what state precedents federal courts must follow, see Kurland, supra note 6, at 205-11; Mishkin, The Variousness of "Federalism": Competence and Discretion in the Choice of National and State Rules for Decision, 105 U. PA. L. Rev. 797 (1957). If the Bernhardt dicta becomes established, any harshness Erie creates by requiring federal courts to follow state precedent, no matter how obsolete, will be greatly ameliorated. Litigants in federal courts will have equal opportunity with those in state courts to have precedents reviewed and modernized. See note 40 infra.

The district court in Shapiro may have felt justified by the Supreme Court decision in Riverbank Laboratories v. Hardwood Products Corp., 350 U.S. 1003 (1956), to disregard old state law and follow the principles of International Shoe Co. v. Washington, 326 U.S. 310 (1945). See 152 F. Supp. at 725; note 14 supra.

40. If the federal court must follow existing state precedents strictly, a different form of forum shopping might replace that which Erie sought to abolish. Litigants who desired the state law as it was, and who did not want any change, would select the federal court because that court would be without authority to modernize state precedents. Those who disliked the state law and desired a change would prefer the state courts as the only courts with power to review and overrule. If a plaintiff started in the state court, the defendant counting on an existing though old state precedent would be well advised to remove to the federal court. Kurland, supra note 6 , at 212 .

The danger in constricting federal interpretation of state law is increased if historically procedural rules are defined as substantive. Local substantive law is usually kept fairly well up-to-date by the legislature or the litigants themselves. But in matters traditionally procedural, old laws often remain unchanged since it is ordinarily easier and cheaper for parties to comply with, rather than challenge, the existing law. See note 41 infra; Note, 56 Colun. L. REv. 394, 400-01 (1956).

41. State definitions of doing business are often outdated. Compare Lutz v. Foster \& Kester Co., $367 \mathrm{~Pa} .125,79$ A.2d 222 (1951) (corporation which had sales and executive office in state through which orders and complaints were processed held not doing business) ; G. W. Bull \& Co. v. Boston \& Me. R.R., 344 Ill. 11, 175 N.E. 837 (1931) (mere solicitation of orders not sufficient), with International Shoe Co. v. Washington, 326 U.S. 310 (1945) ; McGee v. International Life Ins. Co., 355 U.S. 220 (1957). Federal courts in Pennsylvania and Illinois have felt obliged to follow their state precedents strictly. Partin v. Michaels Art Bronze Co., 202 F.2d 541, 544 (3d Cir. 1953) ; Canvas Fabricators, Inc. v. William E. Hooper \& Sons Co., 199 F.2d 485, 487 (7th Cir. 1952). A plaintiff in either Pennsylvania or Illinois wishing to sue a foreign corporation which is doing no more than soliciting orders within the state should sue in the state court and press for liberalization of the state rule. See note 40 supra. 
Within the framework of congressional supervision, the federal courts should, while applying state law on matters historically procedural, be able to determine for themselves if state precedents retain vitality. ${ }^{42}$

42. See note 39 supra.

If federal courts are just other courts of the state in which they sit, they should at least be able to do what other state courts do and refuse to follow obsolete precedents. Of course, federal courts unlike lower state courts are not subject to review by other state tribunals, but this is not a serious fault. While federal courts may occasionally generate a result different from the state, the decisions would have no stare decisis effect. Thus, if the result is disapproved by the state, it is likely to be restricted to one case, for the state legislature or courts remain free to establish their own position which federal courts in the future would have to follow.

Several methods have been proposed for determining state law. One is to allow federal courts to consider all relevant matter in determining the current validity of state precedent. This was suggested shortly after Erie by Corbin, The Lazus of the Several States, 50 YaLE L.J. 762, 771 (1941), and quite recently in Bernhardt v. Polygraphic Co., 350 U.S. 198 (1956). Another is to stay the federal proceeding until the issue is settled in a state court. This is not altogether satisfactory because of the delay involved unless the issue is pending in a state court or a suit to determine the issue can be immediately begun. Staying federal actions pending state determination has been employed in nondiversity cases but rejected in diversity situations. Compare Spector Motor Serv. Inc. v. McLaughlin, 323 U.S. 101, 106 (1944), with Propper v. Clark, 337 U.S. 472, 490-92 (1949). See, generally, HART \& Wechsler, The Federal Courts and the Federal System 869-73 (1953); Note, 25 INv. L.J. 316 (1950). Perhaps a better solution would be to decline jurisdiction in diversity cases where state law is unclear, but this method was effectively blocked in Meredith v. Winter Haven, 320 U.S. 228 (1943). A fourth, and as yet untested, method is to have the federal court certify the unsettled issue of state law to the state supreme court for resolution. Florida has enacted such a statute but it has apparently not been utilized. Fla. Stat. Ans. \$25.031 (Supp. 1957) ; Vestal, The Certified Question of Law, 36 Iowa L. Rev. 629, 643 (1951); Kurland, stipra note 6, at 214.

The approach suggested in Bernhardt appears to be the most realistic, but its future depends on its acceptance and utilization without abuse by the lower federal courts. See Kurland, supra note 6, at 214. The Massachusetts district court used this approach, contrary to precedent, even before Bernhardt. London's, Inc. v. Mack Shirt Corp., 114 F. Supp. 883, 884 (D. Mass. 1953). 